\title{
BIOMARKERS OF DISEASES: AN EVIDENCE-BASED APPROACH
}

\author{
Suetlana Ignjatović, Nada Majkić-Singh \\ Institute of Medical Biochemistry, Clinical Center of Serbia and School of Pharmacy, \\ University of Belgrade, Belgrade, Serbia
}

\begin{abstract}
Summary: Evidence-based medicine (EBM) combines individual clinical expertise with the best available clinical evidence from systematic research in making decisions about the care of individual patients. Clinical expertise is the proficiency and judgment that individual clinicians acquire through knowledge, clinical experience, and practice. Clinical evidence comes from patient-centered clinical research which investigates the accuracy and precision of diagnostic tests and biomarkers, the efficacy and safety of therapeutic regimes, and the reliability of prognostic indicators. The powerful combination of clinical expertise and documented evidence results in safer, more efficacious and accurate care of the patient. Evidence-based guidelines are commonly used tools for supporting medical decisions. Formulating evidence-based recommendations has become a leading principle in guideline development. In laboratory medicine, guidelines provide recommendations on the use of a wide range of tests in detecting or predicting a target condition, for staging and monitoring a disease, and for decisions to initiate, modify, or terminate treatments. Systematic, standardized, and explicit methodology, adapted to laboratorymedicine, should be followed when developing recommendations involving the use of laboratory tests and biomarkers. There are many opportunities for the application and evaluation of laboratory tests in good clinical trials. There are even greater opportunities for correlating various laboratory procedures with the clinical findings, outcomes and diagnoses, and using the stored samples collected for those studies. In this era of evidence-based medicine, clinicians and other decision-makers turn to the scientific literature for high-quality evidence about the usefulness, precision, and accuracy of diagnostic tests. Such evidence is needed more than ever because the list of diagnostic tests is growing exponentially, and even more biomarkers, proteomics, and applications of gene expression profiling will be added in the years to come.
\end{abstract} guidelines

Key words: evidence-based medicine, evidence-based laboratory medicine, biomarkers, evidence-based

\section{Introduction}

Evidence-based medicine (EBM) challenges clinicians and laboratory professionals to make rational decisions in healthcare. The most common definition of EBM comes from Dr. David Sackett. EBM is »the conscientious, explicit and judicious use of current best evidence in making decisions about the care of the individual patient. It means integrating individual clinical expertise with the best available external clinical evidence from systematic research« (1).

EBM is the integration of clinical expertise, patient values, and the best evidence into the decision making process for patient care. Clinical expertise

Address for correspondence:

Svetlana Ignjatović

Institute of Medical Biochemistry, Clinical Centre of Serbia

and School of Pharmacy

Višegradska 26, 11129 Belgrade, Serbia

e-mail: tana@eunet.yu refers to the clinician's cumulated experience, education and clinical skills. The patient brings to the encounter his or her own personal and unique concerns, expectations, and values. The best evidence is usually found in clinically relevant research that has been conducted using sound methodology (2). The purpose of evidence-based medicine is to demonstrate and document best medical practice on the basis of published studies and expert consensus. The »level of evidence» is graded on a scale from $A$ to $E$, with A representing the highest level of evidence and $E$ the lowest. EBM requires new skills of the clinician, including efficient literature-searching, and the application of formal rules of evidence in evaluating the clinical literature. The practice of evidence-based medicine is a process of lifelong, self-directed, problem-based learning in which caring for one's own patients creates the need for clinically important information about diagnosis, prognosis, therapy and other clinical and health care issues (3). The practice of EBM involves the following steps: 
1. construct a relevant, answerable question from a clinical case;

2. plan and carry out a search for clinical literature;

3. critically appraise the literature for validity and usefulness;

4. apply the results of this appraisal to your clinical practice.

The practice of EBM advocates that clinicians search the published literature to find answers to their clinical questions. There are literally millions of published reports, journal articles, correspondence and studies available to clinicians. Choosing the best resource to search is an important decision. A large database such as MEDLINE gives access to the primary literature. Secondary resources such as ACP Journal Club, POEMS, Clinical Inquiries and Clinical Evidence provide assessment of the original study. The Cochrane Library provides access to systematic reviews which help summarize the results from a number of studies (3-5).

In this era of evidence-based medicine, clinicians and other decision-makers turn to the scientific literature for high-quality evidence about the usefulness, precision, and accuracy of diagnostic tests. Such evidence is needed more than ever because the list of diagnostic tests is growing exponentially, and even more biomarkers, proteomics, and applications of gene expression profiling will be added in the years to come (6).

\section{Evidence-Based Laboratory Medicine}

Some of the barriers for the laboratory medicine community are not significantly different from those faced by physicians trying to adapt to an evidencebased world. Many clinical and laboratory professionals in all disciplines have felt uncomfortable with evidence-based practice and with the challenge of the clinical consultant role. This has not been made easier by laboratory reorganization, which has often promoted an industrial rather than a clinical model for laboratory medicine. There is little doubt that the way laboratory data are presented to clinicians is not user-friendly and does not help them with decision making (7).

"Evidence-based laboratory medicine (EBLM) integrates into clinical decision making the best available research evidence for the use of laboratory tests with the analytical and clinical expertise and experience of health care professionals and the needs and expectations of patients « (8). Practicing EBLM has four dimensions: (a) identification of the question; (b) critical assessment of the best evidence available, embodying the principles of health technology assessment; (c) implementation of best practice; and (d) maintaining best practice; the latter embodies the principles of clinical audit (9). The travails of evidence-based laboratory medicine are similar to those faced by clinicians. Preanalytical, analytical, postanalytical, and other technical or organizational elements of diagnostic performance should be seen as part of evidence-based laboratory medicine. We might not always be able to identify in quantitative terms the impact of all elements of test performance on clinical outcomes in laboratory medicine. The need to improve the quality and reporting of randomized control trials led to the Consolidated Standards of Reporting Trials (CONSORT) statement $(10,11)$, and it is hoped that the Standards for Reporting of Diagnostic Accuracy (STARD) statement will lead to a complete and accurate reporting of studies on diagnostic accuracy $(12,13)$.

\section{Evidence-based guidelines in laboratory medicine}

Guidelines are commonly used tools for supporting medical decisions. Formulating evidence-based recommendations has become a leading principle in guideline development. Guidelines should be developed in a transparent process by a multidisciplinary team, with graded recommendations based on critically appraised scientific studies. Systematic, standardized, and explicit methodology, adapted to laboratory medicine, should be followed when developing recommendations involving the use of laboratory tests. Guidelines combine scientific evidence with patients' choices, clinicians' experience, and the availability of resources $(14,15)$.

In laboratory medicine, guidelines provide recommendations on the use of a wide range of tests in detecting or predicting a target condition, for staging and monitoring a disease, and for decisions to initiate, modify, or terminate treatments (13). Also, high-level diagnostic evidence is particularly scarce, and the link between diagnostic tests and better patient outcomes is often unknown (16). Evidence-based guideline development is a hard, time-consuming, and costly exercise. Producing high-quality, scientifically sound, practical, clinically and socially acceptable, and continuously updated recommendations requires special skills and standardized procedures. High-quality guidelines are based on evidence as well as a broad consensus of opinions, which facilitates the acceptance and effective use of the guideline in the target group (17). To ensure high quality, guidelines should be developed within a structured and coordinated program according to the principles of evidence-based guideline development (18).

The AGREE (Appraisal of Guidelines Research and Evaluation) Instrument is a tool for assessing the quality of clinical guidelines according to 23 criteria, grouped into 6 domains (scope and purpose, stake-holder involvement, methodology, clarity and presentation, applicability, and editorial independence). The Instrument is available in more than 10 languages and is currently used in many countries around the world. The AGREE criteria mainly concern the methods used 
for developing the guideline and the quality of reporting $(19,20)$. Watine et al (21) report the results of their test of the correlation between guideline quality and clinical validity of recommendations for 11 guidelines on a specific topic (non-small cell lung cancer) in laboratory medicine. Guideline quality was measured with the AGREE Instrument summarized in a global score. This study is the first to test the relationship between the AGREE quality scores and the clinical content of guidelines, a process that could be considered as a next step in validating the AGREE Instrument. The results revealed that there was no relationship: "good" as well as "not so good" guidelines contained "good" recommendations, corresponding with the evidence of the systematic review, and even "good" guidelines included "not so good" recommendations. These findings confirm the variability of the translation of evidence into practice recommendations by different guideline groups. Further validation of the AGREE Instrument would be the next step in achieving more international consensus about guideline quality and methodology $(18,22)$.

For many reasons, the methodologic quality of diagnostic guidelines is poorer than that of therapeutic guidelines, particularly in the field of laboratory medicine $(14,21,22)$. Laboratory professionals should be involved in guideline development if laboratory tests are included in clinical recommendations. On the other hand, guidelines developed exclusively by laboratory professionals are equally of limited value in terms of both recognition and implementation. They can, however, serve as a position statement of the discipline and as a starting point for further (or local) multidisciplinary development of clinical guidelines. Because of the size and complexity of the task, guideline development is best coordinated by national or international organizations specialized in the field (14).

\section{Biomarkers of diseases: an evidence-based approach}

Laboratory medicine also provides some of the more overt examples of practice lacking a good foundation of evidence, the best examples perhaps being the variations seen in testing strategies between different hospitals for the same clinical presentations. Systematic, standardized, and explicit methodology, adapted to laboratory medicine, should be followed when developing recommendations involving the use of laboratory tests and biomarkers.

There are many opportunities for the application and evaluation of laboratory tests in good clinical trials. There are even greater opportunities for correlating various laboratory procedures with the clinical findings, outcomes and diagnoses, and using the stored samples collected for those studies. Cholesterol was earlier used as an example of a laboratory test, with its clinical use having been clearly established by many large clinical trials. There have been many large and expensive clinical outcome studies that have looked at major endpoints such as myocardial infarction, mortality, and complication rates (25). Laboratory testing cannot attract funding for similar studies. However, there is an opportunity for much greater involvement in these clinical trials (7).

Another example is C-reactive protein, which has very low diagnostic specificity, but has long been used as an acute-phase marker of injury, infection, and inflammation and may also indicate future cardiovascular disease (26). Recent evidence has shown that inflammation plays a pivotal role in the inception and progression of atherosclerosis, and population studies have demonstrated a strong and independent association between baseline concentrations of inflammatorybiomarkers and future coronary events (27-30). Because the majority of individuals who develop coronary events are not in a high-risk group according to the Framingham risk assessment of traditional risk factors for coronary heart disease, and because one half of those who suffer myocardial infarctions have normal lipid values, measurement of inflammatory markers has been suggested as an adjunct to lipid testing to better identify individuals at increased risk (31). Of the inflammatory markers evaluated by the CDC and American Heart Association (AHA) Panel in 2002 (32, 33), only C-reactive protein (CRP) met the analytical requirements for outpatient clinical use and, therefore, has been studied intensely over the past decade. More than 25 prospective epidemiologic studies have shown that CRP is a strong and independent predictor of future myocardial infarction, ischemic stroke, peripheral arterial disease, and sudden cardiac death in apparently healthy men and women (34). Guidelines regarding the potential usefulness of CRP in primary and secondary prevention settings have been issued by the CDC and AHA (32). To assess CHD risk, CRP must be measured by highly sensitive methods (hsCRP) that are capable of reliably measuring concentrations within the healthy reference interval. Currently, more than 30 such methods are available world-wide, many of which have been cleared by the US Food and Drug Administration (FDA). The FDA issued new guidelines for industry and FDA staff regarding this analyte, entitled Review Criteria for Assessment of C-Reactive Protein (CRP), High Sensitivity C-Reactive Protein (hsCRP) and Cardiac C-Reactive Protein (cCRP) Assays (35).

An accurate, noninvasive, and efficient method of detecting substantial coronary artery disease in otherwise apparently low-risk patients remains an unmet need. In the emergency department setting, the subpopulations of patients who represent the greatest challenge in decision making are these lowrisk patients. Published literature was systematically reviewed to determine the diagnostic accuracy of new protein markers of acute coronary syndromes (ACS) in symptomatic outpatients at low risk of ACS and related complications comparable to patients evaluated 
in emergency department chest pain units. Published evidence is not sufficient to support the routine use of new protein markers in screening for ACS in the emergency department setting (36).

The newly revised definition of acute myocardial infarction (AMI) required specific clinical and/or electrocardiographic findings to be coupled with increased blood concentrations of myocardial troponin (released into the circulation after myocardial cell death). Troponin (I or T) is the favored biomarker for myocardial necrosis because it is both highly sensitive and specific $(37,38)$. Furthermore, the document confirmed that a normal electrocardiogram (ECG) does not rule out myocardial infarction because the new, sensitive biomarkers detect very small amounts of myocardial necrosis in a range where ECG abnormalities may not develop. According to the consensus document of 2000, myocardial infarction would be diagnosed if an appropriately timed blood sample contained a troponin concentration that exceeded that at the 99th percentile of a reference population, or contained a troponin concentration that exceeded the concentration at which the assay achieved a $10 \% \mathrm{CV}$ if that concentration was higher than the concentration at the 99th percentile. The consensus document specified that the interval between successive troponin samples should be $6 \mathrm{~h}$. MacRae et al (39) determined that an interval as short as $3 \mathrm{~h}$ between troponin samples yielded the same accuracy in defining an acute myocardial infarction as the 6-h samples used previously. However, this conclusion applied only when the reference sample was taken at least $6 \mathrm{~h}$ after the onset of THE symptoms of myocardial infarction (39). The results of the data presented by MacRae et al (39) will be of considerable interest to clinicians seeking urgent or emergent revascularization of ischemic myocardium. The results of their trial could enable clinicians to identify an acute myocardial infarction earlier than had been thought to be the case in the past (39).

It is also recognized that clinicians will be faced with the determination of D-dimer as a laboratory test that is said to detect venous pulmonary embolism, and the measurement of D-dimer has been studied extensively as an adjuvant test in the diagnosis of deep venous thrombosis (DVT). The turbidimetric D-dimer test is sensitive but nonspecific for the detection of pulmonary embolism in the emergency department setting, and D-dimer tests using latex turbidimetric methods appear to have test characteristics comparable to those for ELISA methods (40). On the other hand, the use of D-dimer assays as a rule-out test for DVT is controversial. If the sensitivity of the D-dimer test for DVT is consistently very high, its negative predictive value will also be high and reliably exclude the presence of disease. These are characteristics of a good »rule-out" test. As such, the use of the D-dimer assay has been suggested as an initial test to rule out DVT in order to reduce the number of patients requiring diagnostic imaging. Heim et al re- viewed 23 studies on the use of D-dimer assays in the diagnosis of lower extremity DVT. Their review of the accuracy of the literature does not support general use of the D-dimer assay as a stand-alone rule-out test for DVT. We found wide variation in the sensitivities of D-dimer assays for diagnosing DVT and even wider variation in specificities. Test characteristics were frequently inconsistent with those of a good rule-out test (41).

One study (21) assessed to what extent methodologic quality is linked to recommendation validity in practice guidelines for the use of laboratory tests in the management of patients with non-small cell lung cancer (NSCLC), specifically laboratory tests measuring quantities in biological specimens, thus excluding tissue (or anatomic) pathology tests. They conducted a systematic review of data on laboratory tests in NSCLC published in English or in French within the last 10 years and retrieved 11 practice guidelines for the use of these tests. The guidelines were critically appraised and scored for methodologic quality and recommendation validity based on the AGREE criteria and the systematic review. Overall, these 11 guidelines had considerable shortcomings in methodologic quality and, to a lesser extent, in recommendation validity. Practice guidelines with the best methodologic quality were not necessarily the most valid in their recommendations, and conversely. Poor methodologic quality and lack of recommendation validity in laboratory medicine call for methodologic standards of guideline development and for international collaboration of guideline development agencies. They advise readers of guidelines to critically evaluate the methods used, as well as the content of the recommendations, before adopting them for use in practice.

The incidence of acute and chronic heart failure has increased substantially during recent decades because of aging populations in the Western world, arising, at least partially, from medical progress with extended life expectancies. The diagnosis and prognostic evaluation of heart failure are still challenging problems in clinical medicine because simple and accurate diagnostic techniques are not available. In daily routine, diagnosis of heart failure is based mainly on the patient's history and clinical findings and, occasionally, on the echocardiographic evaluation of the left ventricular (systolic) function and dimensions. Natriuretic peptides are promising markers in diagnosing acute and chronic heart failure and assessing prognosis in these patients. Increasing routine use for unselected patients is challenged by false-positive results. Most recently, it has been confirmed that NTproBNP is a promising marker for the identification of patients with structural heart disease in the emergency room and a suitable tool for risk stratification, but its use for the emergency room should at present be limited to clearly clinically defined patient groups to avoid a potential excess of additional diagnostic procedures in positive but asymptomatic patients (42). 
The landscape of prostate cancer has changed since the appearance of the first prostate-specific antigen (PSA) assay. Key elements in PSA measurement are the interchangeability of assays and the stability of serum samples before tests $(43,44)$. Following the critical appraisal of the available information, criteria have been proposed to help physicians use the information from published studies to estimate the real usefulness of total and free prostate-specific antigens (tPSA and fPSA) in clinical decisions about prostate carcinoma. Different assays for the concentrations of tPSA and fPSA provide discordant results (45). These assay-dependent variations could lead to the misinterpretation of individual PSA values and erroneous clinical decisions about prostate carcinoma. Stephan et al (46) showed that the interchangeability of methods is a problem for clinical samples. In that study, they took great care when storing samples and performing the assay, and the reliability of the measured values was high. The percentage free PSA (\%fPSA) is related to both total PSA and free PSA and needs to be evaluated carefully. As Stephan et al indicated, for patients in whom the \%fPSA determines whether a prostate biopsy is performed, the result might depend on the assay used. Thus it seems important that total and free PSA be measured by compatible methods. Interchangeability of tPSA, fPSA, and \%fPSA values obtained by commercial PSA assays remains inadequate, but attention to this issue may minimize the misinterpretation of PSA results obtained by different assays (46).

There are also evidence-based studies for the performance characteristics of urinary bone markers for monitoring the treatment of osteoporosis, because the usefulness of urinary markers of bone turnover in monitoring therapy depends on their within-person variability (47-49). All of these studies link laboratory and clinical medicine through analysis that is data-driven and critically evaluated.

Acknowledgements: The present work was supported by the Ministry of Science, Technologies and Development of Serbia, on the basis of Contract $\mathrm{N}^{\circ}$ 145010.

\title{
BIOMARKERI OBOLJENJA: PRISTUP ZASNOVAN NA DOKAZIMA
}

\author{
Suetlana Ignjatović, Nada Majkić-Singh \\ Institut za medicinsku biohemiju, Klinički centar Srbije i Farmaceutski fakultet \\ Univerziteta u Beogradu, Beograd, Srbija
}

\begin{abstract}
Kratak sadržaj: Medicina zasnovana na dokazima (EBM) pri donošenju odluka o nezi pacijenata kombinuje individualnu kliničku veštinu sa najboljim raspoloživim kliničkim dokazima iz sistematičnih istraživanja. Klinička veština odlikuje se tačnošću u proceni i stiče se učenjem, kliničkim iskustvom i praksom. Klinički dokazi dobijaju se iz kliničkih istraživanja koja su usmerena na pacijenta, a koja ispituju tačnost i preciznost dijagnostičkih testova i biomarkera, efikasnost i sigurnost terapeutskih postupaka i pouzdanost prognostičkih indikatora. Kombinacija kliničke veštine i dokumentovanih dokaza omogućava sigurniju, efikasniju i pouzdaniju negu pacijenta. Vodiči zasnovani na dokazima najčešće se koriste kao dodatne alatke pri donošenju medicinskih odluka. Formulisanje preporuka zasnovanih na dokazima predstavlja vodeći princip u pripremi vodiči. U razvoju preporuka koje uključuju laboratorijske testove i biomarkere treba primeniti sistematsku i standardizovanu metodologiju koja je prilagođena laboratorijskoj medicini. Postoji veliki broj mogućnosti za primenu i evaluaciju laboratorijskih testova u dobrim kliničkim ispitivanjima. Još su veće mogućnosti za uspostavljanje korelacija između različitih laboratorijskih postupaka i kliničkih nalaza, ishoda i dijagnoza, kao i za korišćenje uzoraka koji su skladišteni za ova ispitivanja. Era medicine zasnovane na dokazima zahteva od eksperata koji donose medicinske odluke proučavanje naučne literature kako bi se obezbedio visok kvalitet dokaza o korisnosti i tačnosti dijagnostičkih testova. Ovakva vrsta dokaza potrebnija je više nego ikad zato što lista dijagnostičkih testova raste eksponencijalno i u godinama koje dolaze na nju će biti dodato još više biomarkera, proteomike i aplikacija profiliranja ekspresije gena.
\end{abstract}

Ključne reči: medicina zasnovana na dokazima, laboratorijska medicina zasnovana na dokazima, biomarkeri, laboratorijska vodiči zasnovana na dokazima 


\section{References}

1. Sackett DL, Rosenberg WMC, Gray JAM, Haynes RB, Richardson WS. Evidence-based medicine: what it is and what it isn't. Br Med J 1996; 312: 71-2.

2. Sackett DL, Straus SE, Richardson WS, Rosenberg W, Haynes RB. Evidence-based medicine; how to practise and teach EBM. 2nd ed. Edinburgh: Churchill Livingstone, 2000: 82-4.

3. Anonymous. Evidence and diagnostics. Bandolier Extra 2002 (February): 1-9 (full text available on: http: //www.ebandolier.com

4. Cochrane Library. http://www.cochrane.org (accessed June 2006).

5. Centre for Evidence-Based Medicine. Learning EBM. http://ww.cebm.net (accessed June 2006).

6. Bossuyt PMM. The quality of reporting in diagnostic test research: getting better, still not optimal Clin. Chem. 2004; 50: 465-6.

7. McQueen MJ. Overview of evidence-based medicine: challenges for evidence-based laboratory medicine. Clin Chem 2001; 47: 1536-46.

8. http://www.ifcc.org (accessed June 2006).

9. Price CP. Evidence-based laboratory medicine: supporting decision-making. Clin Chem 2000; 46: 1041-50.

10. Begg C, Cho M, Eastwood S, Horton R, Moher D, Olkin I, et al. Proving the quality of reports of randomized controlled trials in the CONSORT statement. JAMA 1996; 276: 637-9.

11. Altman DG. Better reporting of randomized controlled trials: the CONSORT statement. Authors must provide enough information for readers to know how the trial was performed [Editorial]. BMJ 1996; 313: 570-1.

12. Bossuyt PM, Reitsma JB, Bruns DE, Gatsonis CA, Glasziou PP, Irwig LM, et al. Towards complete and accurate reporting of studies of diagnostic accuracy: the STARD initiative. Clin Chem 2003; 49: 1-6.

13. Bossuyt PM, Reitsma JB, Bruns DE, Gatsonis CA, Glasziou PP, Irwig LM, et al. The STARD Statement for reporting studies of diagnostic accuracy: explanation and elaboration. Clin. Chem. 2003; 49: 7-18.

14. Oosterhuis WP, Bruns DE, Watine J, Sandberg S, Horvath AR. Evidence-based guidelines in laboratory medicine: principles and methods. Clin Chem 2004; 50: 806-18.

15. Haynes RB, Devereaux PJ, Guyatt GH. Physicians - and patients - choices and evidence-based practice. BMJ 2002; 324: 1350.

16. J. S. Burgers. Guideline quality and guideline content: are they related? Clin Chem 2006; 52: 3-4.

17. Grol R, Dalhuijsen J, Thomas S, Veld C, Rutten G, Mokkink $\mathrm{H}$. Attributes of clinical guidelines that influence use of guidelines in general practice: observational study. BMJ 1998; 317: 858-61.
18. Burgers JS, Cluzeau FA, Hanna SE, Hunt C, Grol R. Characteristics of high quality guidelines: evaluation of 86 clinical guidelines developed in ten European countries and Canada. Int $\mathrm{J}$ Technol Assess Health Care 2003; 19: 148-57.

19. The AGREE Collaboration. Development and validation of an international appraisal instrument for assessing the quality of clinical practice guidelines: the AGREE project. Qual Saf Health Care 2003; 12: 18-23.

20. The AGREE Collaboration. AGREE Instrument training manual, 2003. http://www.agreecollaboration.org (accessed June 2006).

21. Watine J, Friedberg B, Charet JC, Nagy E, Onody $\mathrm{R}$, Oosterhuis $\mathrm{W}$, et al. Conflict between guideline methodologic quality and recommendation validity: a potential problem for practitioners. Clin Chem 2006; 52: $65-72$.

22. McCormack J, Perry T, Jr, Rangno R, Van Breemen C, Wright JM, Baltzan M, et al. Assessing the quality of clinical practice guidelines. CMAJ 2002; 166: 168-9.

23. Horvath AR, Nagy E, Watine J. Quality of guidelines for the laboratory management of diabetes mellitus. Scand J Clin Lab Invest Suppl 2005; 240: 41-50.

24. Irani J, Brown CT, van der Meulen J, Emberton M. A review of guidelines on benign prostatic hyperplasia and lower urinary tract symptoms: are all guidelines the same? BJU Int 2003; 92: 937-42.

25. Expert Panel on Detection, Evaluation, and Treatment of High Blood Cholesterol in Adults. Executive summary of the Third Report of the National Cholesterol Education Program (NCEP) Expert Panel on Detection, Evaluation, and Treatment of High Blood Cholesterol in Adults (Adult Treatment Panel III). JAMA 2001; 19: 2486-97.

26. Pepys MB, Berger A. The renaissance of C-reactive protein [Editorial]. BMJ 2001; 322: 4-5.

27. Ledue TB, Rifai N. Preanalytic and analytic sources of variations in C-reactive protein measurement: implications for cardiovascular disease risk assessment. »Review«. Clin Chem 2003; 49: 1258-71.

28. Ridker PM. Clinical application of C-reactive protein for cardiovascular disease detection and prevention. Circulation. 2003; 107: 363-9.

29. Rifai N, Ballantyne CM, Cushman M, Levy D, Myers GL. Point: high-sensitivity $\mathrm{C}$-reactive protein and cardiac $\mathrm{C}$ -reactive protein assays: is there a need to differentiate? Clin Chem 2006; 52: 1254-6.

30. Callaghan JV, Gutman SI. Counterpoint: Food and Drug Administration guidance for C-reactive protein assays: matching claims with performance data. Clin Chem 2006; 52: 1256-7.

31. Khot UN, Khot MB, Bajzer CT, Sapp SK, Ohman EM, 
Brener SJ, et al. Prevalence of conventional risk factors in patients with coronary heart disease. JAMA 2003; 290: 898-904.

32. Pearson TA, Mensah GA, Alexander RW, Anderson JL, Cannon RO III, Criqui $M$, et al. Markers of inflammation and cardiovascular disease: application to clinical and public health practice: a statement for healthcare professionals from the Centers for Disease Control and Prevention and the American Heart Association. Circulation 2003; 107: 499-511.

33. Myers GL, Rifai N, Tracy RP, Roberts WL, Alexander RW, Biasucci LM, et al. CDC/AHA workshop on markers of inflammation and cardiovascular disease: application to clinical and public health practice: report from the laboratory science discussion group. Circulation 2004; 110: e545-e549.

34. Ridker PM, Wilson PW, Grundy SM. Should C-reactive protein be added to metabolic syndrome and to assessment of global cardiovascular risk? Circulation 2004; 109: 2818-25.

35. US Food and Drug Administration. Review criteria for assessment of C-reactive protein (CRP), high sensitivity C-reactive protein, and cardiac C-reactive protein (cCRP) assays. 2005. http://www.fda.gov/cdrh/oivd/guidance/1246.pdf (accessed November 2005).

36. Mitchell Alice M, Brown Michael D, Menown Ian B.A, and Kline Jeffery A. Novel protein markers of acute coronary syndrome complications in low-risk outpatients: a systematic review of potential use in the emergency department. Clin Chem 2005; 51: 2005-12.

37. Myocardial infarction redefined-a consensus document of the joint European Society of Cardiology/American College of Cardiology committee for the redefinition of myocardial infarction. Eur Heart J 2000; 21: 1502-13.

38. Myocardial infarction redefined-a consensus document of the joint European Society of Cardiology/American College of Cardiology committee for the redefinition of myocardial infarction. J Am Coll Cardiol 2000; 36: 959-69.

39. MacRae AR, Kavsak PA, Lustig V, Bhargava R, Vander- sluis R, Palomaki GE, et al. Assessing the requirement for the 6-hour interval between specimens in the American Heart Association classification of myocardial infarction in epidemiology and clinical and research studies. Clin Chem 2006; 52: 812-8.

40. Brown MD, Lau J, Nelson RD, Kline JA. Turbidimetric D-dimer in the diagnosis of pulmonary embolism: a meta-analysis. Clin Chem 2003; 49: 1846-53.

41. Heim SW, Schectman JM, Siadaty MS, Philbrick JT. D-Dimer testing for Deep Venous Thrombosis: a metaanalysis. Clin Chem 2004; 50: 1136-47.

42. Möckel M, Müller R, Vollert JO, Müller C, Carl A, Peetz $\mathrm{D}$, et al. Role of $\mathrm{N}$-terminal pro-B-type natriuretic peptide in risk stratification in patients presenting in the emergency room. Clin Chem 2005; 51: 1624-31.

43. Jung K, Von Klinggräff P, Brux B, Sinha P, Schnorr D, Loening SA. Preanalytical determinations of total and free prostate-specific antigen and their ratio: blood collection and storage condition. Clin Chem 1998; 44: 685-8.

44. Woodrum D, York L. Two-year stability of free and total PSA in frozen serum samples. Urology 1998; 52: 247-51.

45. Semjonow A, De Angelis G, Oberpenning F, Schmid HP, Brandt B, Hertle L. The clinical impact of different assays for prostate specific antigen. BJU Int 2000; 86: 590-7.

46. Stephan C, Klaas M, Muller C, Schnorr D, Loening SA, Jung K. Interchangeability of measurements of total and free prostate-specific antigen in serum with 5 frequently used assay combinations: an update. Clin Chem 2006; 52: 59-64.

47. Worsfold M, Powell DE, Jones T, Davie MW. Assessment of urinary bone markers for monitoring treatment of osteoporosis. Clin Chem 2004; 50: 2263-70.

48. Beastall G. Evidence-based osteoporosis. Jug Med Biohem 2004; 23 (3): 213-9.

49. Emerk K. Bone markers and osteoporosis. Jug Med Biohem 2004; 23 (3): 221-8.

Received: July 21, 2006

Accepted: August 15, 2006 